\title{
Anzaldúa's Frontera: Inscribing Gynetics
}

\author{
Norma ALARCóN \\ Universidad de California, Berkeley
}

The Inscription of the Subject

In our time the very categorical and/or conceptual frameworks through which we explicitly or implicitly perceive our sociopolitical realities and our own subjective (private) contextual insertion, are very much in question. Theoretically infused writing practices as those found in anthologies such as This Bridge Called my Back, All the Women Are White, All Blacks Are Men, but Some of Us Are Brave, Making Face, Making Soul/Haciendo Caras, not to mention the flurry of anthologies compiled by African American Critics on Black Women Writers, call attention to the insertion. The self that writes combines a polyvalent consciousness of "the writer as historical subject (who writes? and in what context?), but also writing itself as located at the intersection of subject and history - a literary practice that involves the possible knowledge (linguistical and ideological) of itself as such". Self-inscriptions, as focal point of cultural consciousness and social change [...] weaves into language the complex relations of a subject caught between the contradictory dilemmas of race, gender, ethnicity, sexualities, and class, transition between orality and literacy and the "practice of literature as the very place where social alienation is thwarted differently according to each specific context".

Self-inscription as "focal point of cultural consciousness and social change" is as vexed a practice for the more "organic/specific" intellectual, as it is for the "academic/specific" intellectual trained in institutions whose business is often to continue to reproduce his hegemonic hold on

1 T. Minha TrunH, "Not You/Like You: Post-Colonial Women and the Interlocking Questions of Identity and Difference", in Making Face, Making SoulHaciendo Caras, Creative and Critical Perspectives by Women of Color, p. 245. 
cognitive charting and its (political) distribution in the academy itself. As a result, it should be no surprise that critics of color, in different context than that of Bridge and thus differently articulated, nevertheless critique through their exclusion, their absence or displacement in the theoretical production and positions taken by Euroamerican feminists and African Americanists: "The black woman as critic, says Valerie Smith, and more broadly as the locus where gender-, class- and racebased oppression intersect, is often invoked when Anglo-American feminists and male Afro-Americanists begin to rematerialize their discourse". ${ }^{2}$ Thus cultural/national dislocations also produce cognitive ones as the models which assume dominance increasingly reify their discourse through the use of non-revised theories thus resembling more and more so called "androcentric criticism". In other words, Smith says, "when historical specificity is denied or remains implicit, all the women are presumed white all the blacks male. The move to include black women as historical presences and speaking subjects in critical discourse may well then be used as a defense against charges of racial hegemony on the part of white women and sexist hegemony on the part of black males" ${ }^{3}$ Thus the "black woman" appears as "historicizing presence" which is to say that as the critical gaze becomes more distanced from itself as speaker it looks to "black women" as the objective difference that historicizes the text in the present, signalling the degree to which such theorists have ambiguosly assumed the possition of Same/I. In this circuitous manner the critical eye/I claims Same/not Same, an inescapability that itself is in need of elaboration. I would suggest at this time that it is not so much that, as the possibility that the writing practices we are compelled to work with and their concomitant demands for certain kinds of linear rationality demand that self/other duality. Consequently, the difference within, as such, cannot be grasped, but rather one is forced to discover it in a specular manner in her. She is the "objective" difference which serves to mediate the discourse produced oppositionally to the "Name of the Father and the Place of the Law", which in my view currently accounts for the demand for the texts of "women of color" in the academy, who may soon be supplanted by another. Smith goes on to affirm that as black feminist theorists emer-

2 Valerie SMITH, "Black Feminist Theory and the Representation of the 'Other" ", in Changing Our Own Words: Essays on Criticism, Theory, and Writing by Black Women, p. 44.

${ }^{3}$ Ibid., pp. 44-45. 
ge they challenge "the conceptualizations of literary study and concern themselves increasingly with the effect of race, class, and gender on the practice of literary criticism". 4

My intention here is not so much to produce a "literary criticism" for Chicanas, nor do I want to be limited by the reach of what are perceived as "literary texts". I want to be able to hybridize the textual field so that what is at stake is not so much our inclusion or exclusion in literary/ textual genealogies and the modes of their production, which have a limited, though important critical reach, but to come to terms with the formation and displacement of subjects, as writers/critics/chroniclers of the nation, and the possibility that we have continued to recodify a family romance, an oedipal drama in which the woman of color in the Americas has no "designated" place. She is simultaneously presence/ absence in the configurations of the nation-state and textual representation. Moreover, the moment she emerges as a "speaking subject in process" the here-to-fore triadic in which the modern world has largely taken shape becomes endlessly heterogeneous and ruptures the "oedipal family romance". That is, the underlying structure of the social and cultural forms of the organization of Western societies, which further have been superimposed through systems of domination - political, cultural and theoretical; and which subsequent counter nation-making narratives have adapted which is, in the Americas, disrupted by the voice of writers/critics of color such as Chicanas, so that we must "make familia from scratch".

In an earlier essay, ${ }^{5}$ I appropiated as metonym and metaphor for the referent/figure of the Chicana, the notion of the "differend" from Lyotard, which he defines as "a case of conflic, between (at least) two parties that cannot be equitably resolved for lack of rule of judgement applicable to both arguments. One side's legitimacy does not imply the other's lack of legitimacy". In part her conflictive and conflicted position emerges, as Smith affirms, when the oppositional discourses of "White" Women and "Black" Men vie for her "difference" as materialization and/or a shifting deconstructive maneuver of Patriarchy, "The name of the Father and the place of the Law". Yet one must keep in mind that Lyotard's disquisition on the term doesn't negotiate well the transitions between textual representation, and political/juridical representation. As Fraser has

${ }^{4}$ Ibid., pp. 46-47.

5Norma Alarcón, "Chicana Feminisms: In the Track of the Native Woman", in Cultural Studies. 
noted "There is no place in Lyotard's universe for critique of pervasive axes of stratification, for critique of broad-based relations of dominance and subordination along lines like gender, race and class". ${ }^{6}$ Relations of dominance and subordination arise out of the political economy and the ways in which the nation has generated its own self-representation in order to harness its population towards its own self-projection on behalf of the elite, as such the formation of political economies in tandem with the making of nations provide the locations from which historical material specificity arises generating its own discourses, which philosophically may not coincide with theories of textual representation. The shift from theories of symbolic self-representation to juridical and phenomenological is not seamless, indeed the interstice, discontinuity and gap is precisely a site of textual production. The historical and ideological moment in which the subject inscribes herself. In other words, the historical writing subject emerges into conflictive discourses generated by theories of representation, whether it be juridical, or textual/symbolic. Each is rule-governed by different presuppositions, and a Chicana may have better fortunes at representing herself or being represented textually than legally as a Chicana. That is, the juridical text is generated by the ruling elite who have access to the state apparati through which the political economy is shaped and jurisprudence is engendered, while representation in the cultural text may include representations generated by herself. However, insofar as the latter are, as it were, "marginalia" they not only exist in the interstices, they are produced from the interstices. She, akin to Anzaldúa's "Shadow Beast", sends us in as "Stand-ins", reinforcing and insuring the interstitiality of differend, as the very nonsite from which critique is possible. Her migratory status, which deprives her of the projection of "Home", whether it be a stable town or a nation-state, generates a "acoherent" though cogent discourse that is our task to revise and rewrite.

It is, I believe, in the spirit of the above remarks which are as much produced by my reading of Gloria Anzaldua as hers are produced by her hunger for Representation, for a coming into "being" which Anzaldúa understands to be both the truth and a fiction. A truth as the "Shadow Beast" who is continually complicit with and resistant to the stand-in, conscious will, and who "threatens the sovereignty" of conscious

${ }^{6}$ Nancy Fraser and Linda J. NiChOLSON, "Social Criticism without Philosophy: An Encounter between Feminism and Postmodemism", in Feminism/Postmodernism, p. 23. 
rulership. ${ }^{7}$ The "Shadow Beast", ultimately, undermines a monological self-representation, because it kicks out the constraints and "bolts" "at the least hint of limitations". ${ }^{8}$

\section{Inscribing Gynetics}

Gloria Anzaldúa is a self-named Chicana from Hargill, Texas, a rural town in what is known as El Valle, the Valley. It is an agricultural area notorious for its mistreatment of people of Mexican descent. Indeed, many of the narratives that emerge from that area tell of the conflictive and violent relations in the forging of an anglicized Texas out of the Texas-Coahuila territory of New Spain; as well as of the eventual production of the geopolitical border between Mexico and the United States. These borderlands are spaces where, as a result of expansionary wars, colonization, juridico-immigratory policing, coyote exploitation of emigrés and group-vigilantes, formations of violence are continuously in the making. These have been taking place, as racialized confrontations, at least since the Spanish began to settle Mexico's (New Spain) "northern" frontier of what is now the Angloamericanized Southwest. Subsequently, and especially after the end of the Mexican-American War in 1848, these formations of violence have been often dichotomized into Mexican/American which actually have the effect of muting the presence of indigenous peoples yet setting "the context for the formation of 'races'"? 9

Consequently, the modes of autohistoricization in and of the boderlands often emphasize or begin with accounts of violent racialized collisions. It is not surprising, then, that Anzaldua should refer to the current U.S./ Mexican borderline as an "open wound" from Brownsville to San Diego, from Tijuana to Matamoros, where the former are considerably richer than the latter and the geopolitical line itself artificially divides into a two-class/culture system; that is, the configuaration of the political economy has the "third" world rub against the "first". Though the linguistic and culture systems on the border are highly fluid in their dispersal, the geopolitical lines tend to become univocal, i. e. "mexican" and "anglo".

${ }^{7}$ G. ANZaldúA, op.cit, p. 16.

${ }^{8}$ Idem.

9 David MONTEJANo, Anglos and Mexican in the Making of Texas, 1836-1986, p. 309. 
Of Hargill, Texas and Hidalgo County and environs Gloria Anzaldúa says, "This land has survived possession and ill-use by five powers: Spain, Mexico, the Republic of Texas, the United States, the Confederacy, and the U. S. again. It has survived Anglo-Mexican blood feuds, lynchings, burnings, rapes, pillage". ${ }^{10} \mathrm{Hidalgo}$ is the "most poverty stricken country in the nation as well as the largest home base (along with Imperial Valley in California) for migrant farmworkers". She continues, "It was here that I was born and raised. I am amazed that both it and I have survived"."

Through this geographic space, then, people displaced by a territorialized political economy, whose juridical centers of power are elsewhere, in this case Mexico, D. F. and Washington, D. C., attempt to reduce the level of material dispossession through the production of both counter -and disidentificatory discourses. That is, the land is repossessed in Imaginary terms, both in the Lacanian and Althusserian sense. I shall return below to a more elaborate discussion of this proposition, which I will further also characterize as dialogically paradigmatic and syntagmatic respectively yielding a highly creative heteroglossia.

However, before turning to Anzaldúa's attempt to repossess the borderlands, let's quickly review one area of counteridentificatory or oppositional discursive productions. Thus, for example, Américo Paredes and now his follower José E. Limón, claim El Valle as the site where the Corrido originated. That is, in the Américas in the Valley of a landmass now named Texas a completely "new" genre emerged, the Corrido. As such Limón strategically moves the emergence towards a disengagement from claims of the corrido's origins in Spanish romance -Spain's own border ballads. The Paredes-Limón move could be contextualized as racialized-class-culture based one. The trans(form)ation and trans(figure)ation in raced class-crossing remains unexplored. ${ }^{12}$ That is, the metamorphoses of the Spanish ballad form are induced by the emergence of an oppositional hero in the U. S.-Mexico border whose raced-class position is substantially different. Limón's strategy is in contradiction to that of Maria Herrera-Sobek's in her book The Mexican Corrido: A Feminist Analysis, where she aligns the corrido with the Peninsular origins theory, where border ballads also emerged in the making of Spain. Herrera-Sobek's lack of desire to disengage the formal

${ }^{10}$ G. ANZALDÚa, op.cit., p. 90.

11 Ibid., pp. 98.

12 José E. LiMón, Mexican Ballads, Chicano Poems: History and Influence in MexicanAmerican Social Poetry, chap. 1. 
origins from Spain and relocalize them in Texas could be a function of an implicit feminist position, the representation of women, be it in the romance or the corrido reenact a specularly Manichean scenario in the patriarchal tableau.

The point for my analysis, however, is to call attention to the need to "repossess" the land, especially in cultural nationalist narratives, through scenarios of "origins" that emerge in the selfsame territory, be it at the literary, legendary, historical, ideological, critical or theoretical levelproducing in material and imaginary terms "authentic" and "inauthentic", "legal" and "illegal" subjects. That is the drive to territorialize/ authenticate/legalize and deterritorialize/deauthenticate/delegalize is ever present, thus constantly producing "(il)legal”/(non)citizen subjects both in political and symbolic representations in a geographical area where looks and dress have increasingly telling of one's (un)documented status. ${ }^{13}$ It should be no surprise then, that the Corrido makes a paradigmatic oppositional hero of the persecuted in the figuration of the unjustly Outlaw(ed), the unjustly (un)documented, in Gloria's terms, Queers. Thus, also, in Anzaldúa's terms the convergence of claims to proper ownership of the land "has created a shock culture, a border culture, a third country, a closed country"14 where the "detribalized" population is not only comprised of "females, [...] homosexuals of all races, the darkskinned, the outcast, the persecuted, the marginalized, the foreign" 15 but is also possessed of the "faculty", a "sensing", in short, a different consciousness which as we shall see is represented by the formulation of the consciousness of the "new mestiza", a reconceptualized feminine.

If however, Gregorio Cortés becomes a paradigmatic oppositional corrido figure of Texas-Mexican ethno-nationalism, given new energy after the publication of Paredes With His Pistol in his Hand (1958), Gloria Anzaldúa crosscuts masculine-coded "Text-Mex" nationalism through a configuration of a borderland "Third Country" as a polyvocal rather than univocal Imaginary. She says, "If going home is denied me then I will have to stand and claim my space, making a new culture -una cultura mestiza - with my own lumber, my own bricks and mortar and my ov'a feminist architecture". ${ }^{16}$ To the extent that she wavers in her

\footnotetext{
${ }^{13}$ Debbie NATHAN, Women and Other Aliens: Essays from the U.S.-Mexican Border.

14 G. ANZALDÚA, op.cit., p. 11.

15 Ibid., p. 38.

${ }^{16}$ Ibid., p. 22.
} 
desire for reterritorialization a la Gregorio Cortés oppositional paradigm, the "third country" becomes a "closed country", bounded; to the extent that she wants to undercut the "Man of Reason", the unified sovereign subject of philosophy, she constructs a "crossroads of the self", a mestiza consciousness. Anzaldúa's conceptualization, of the mestiza as a produced vector of multiple culture transfers and transitions corresponds simultaneously to Jameson's version of the Lacanian pre-individualistic "structural crossrads". That is, "in frequent shifts of the subject from one fixed position to another, in a kind of optional multiplicity of insertions of the subject into a relatively fixed Symbolic Order". ${ }^{17}$ It has resonance with Cornelius Castoriadis' version as well:

The subject in question is [...] not the abstract moment of philosophical subjectivity; it is the actual subject traversed through and through by the world and by others [...] It is the active and lucid agency that constantly reorganizes its contents, through the help of these same contents, that produces by means of a material and in relation to needs and ideas, all of which are themselves mixtures of what it has already found there before it and what it has produced itself. ${ }^{18}$

Notwithstanding the different locations of each theorist, Anzaldúa, Jameson, and Castoriadis, the resonance is inescapable. That transversal simultaneity is that one where the speaking subject in process is both traversed "by the world and by others" and takes hold so as to exercise that "lucid agency that constantly reorganizes [...] contents". Now, the relatively fixed Symbolic Order that Anzaldúa's text crosscuts is differently reorganized as Anzaldúa shifts the targets of engagement. It is now cutting across eurohegemonic representations of Woman, now Freudian/Lacanian psychoanalysis ("I know things older than Freud"), 19 through Jungian psychoanthropology, and the rationality of the sovereign subject as she in non-linear and non-developmental ways shifts the "names" of her resistant subject positions - Snake Woman, La Chingada, Tlazoltéotl, Coatlicue, Cihuacóatl, Tonantzin, Guadalupe, La Llorona... The polyvalent name-insertions in Borderlands is a rewriting of the femenine, a reinscription of gynetics. Of such revisionary tactics, Drucilla Cornell says, in another context, "in affirmation, as a positioning, as a

\footnotetext{
${ }^{17}$ Fredric JAMESON, Postmodernism, or, The Cultural Logic of Late Capilalism, p. 354.

${ }^{18}$ Cornelius CASTORIADIS, The Imaginary Institution of Society, p. 106.

19 G. ANZALDÚa, op.cit., p. 26.
} 
performance, rather than of Woman as a description of reality". ${ }^{20}$ Since the category of Woman in the case of Chicanas/Latinas and other women of color have not been fully mapped, nor rewritten across cultureclasses, the multiple-writing, multiple-naming gesture must be carried out given the absence of any shared textualization. Thus, a text such as Anzaldúa's is the "ethnic" performance of an implicitly tangential Derridean deconstructive gesture which "must, by means of a double gesture, a double science, a double writing, practice an overturning [sic] of the classical opposition and [sic] a general displacement [sic] of the system". ${ }^{21}$ That is, through the textual production of, and the speaking position of, a "mestiza consciousness", and the recuperation and recodification of the multiple names of "Woman," Anzaldúa deconstructs ethnonational oppositional consciousness on the one hand, and its doublet, "the Man of Reason".

Insofar as Anzaldua implicity recognizes the power of the nationstate to produce "political subjects" who are now legal, now illegal, deprived of citizenship, she opts for "ethnonationalism" and reterritorialization in the guise of a "closed/third country". While she rejects a masculinist ethnonationalism that would exclude the Queer, she does not totally discard a "neonationalism" (i. e. the "closed/third" country) for the reappropriated borderlands, Aztlán. However, it is now open to all of the excluded, not just Chicanos, but all Queers. That is the formation of a utopic imaginary community in Aztlán would displace the ideology of the "holy family"/"family romance" still prevalent in El Valle and elsewhere in the Southwest, which makes it possible for many to turn away from confronting other social formations of violence.

The imaginary utopic community reconfirms from a different angle Liisa Malkki's claim that our confrontation with displacement and the desire for "home" brings into the field of vision "the sedentarist metaphysic embedded in the national order of things". ${ }^{22}$ That is, the counterdiscursive construction of an alternate utopic imagined community reproduces the "sedentarist metaphysic" in (re)territorialization. Malkki continues, "sedentarist assumptions about attachment to place lead us to

\footnotetext{
${ }^{20}$ Drucilla CORNELL, Beyond Accommodation: Ethical Feminism, Deconstruction and the Law.

2I Jacques DERRIDA, Margins of Philosophy, p. 329.

${ }^{22}$ Liisa MALKKI, "National Geographic: The Rooting of People and the Territorialization of National Identity Among Scholars and Refugees", in Cultural Anthropology: Space, Identity, and the Politics of Difference, p. 31.
} 
define displacement not as a fact about sociopolitical content, but rather as an inner, pathological condition of the displaced". ${ }^{23}$ Anzaldúa has clear recognition of this in the very concept of a "mestiza consciousness" as well as in her privileging of the notion of migratoriness, the multiplicity of our names, and the reclamation of the borderlands in feminist terms that risk the "pathological condition" by representing the non-linearity and the break with a developmental view of self-inscription: "We can no longer blame you nor disown the white parts, the male parts, the pathological parts, the queer parts, the vulnerable parts. Here we are weaponless with open arms, with only our magic. Let's try it our way, the mestiza way, the Chicana way, the woman way". ${ }^{24}$ Indeed the hunger for wholeness -el sentirse completa - guides the chronicles, and that hunger is that same desire that brings into view both the migratoriness of the population and the reappropiation of "Home". That is, in the Américas today, the processes of sociopolitical empire and nation-making displacements over a 500-year history are such that the notion of "Home" is as mobile as the populations, a "home" without juridically nationalized geopolitical territory.

\section{The "Shadow Beast" Moves Us On}

The trope of the "Shadow Beast" in the work of Gloria Anzaldúa functions simultaneously as a trope of a recodified Lacanian unconscious, "as the discourse of the Other" and as an Althusserian Imaginary through which the real is grasped and represented. ${ }^{25}$ That is, the "Shadow Beast" functions as the "native" women of the Américas, as a sign of savagery -the feminine as a sign of chaos. The speaking subject as stand-in for the "native" woman is already spoken for through the multiple discourses of the Other, as both an unconscious and an ideology. Thus, the question becomes what happens if the subject speaks through both simultaneously, and implicity grasping her deconstruction of such discursive structures, proposes the New Consciousness: "This almost finished product seems an assemblage, a montage, a beaded work with several leitmotifs and with a central core, now appearing, now disappearing in a crazy dance". ${ }^{26}$ "It is this learning to live with Coatlicue that transforms living in

23 Ibid., pp. 32-33.

${ }^{24}$ G. ANZALDÚA, op.cit., p. 88.

${ }^{25}$ Jacques LACAN, Ecrits; Louis ALTHUSSER, Lenin and Philosophy and Other Essays.

${ }^{26}$ G. ANZALDÚA, op.cit., p. 66. 
the borderlands from a nightmare into a numinous experience. It is always a path/state to something else". ${ }^{27}$

The Lacanian linguistic unconscious sets in motion a triangulated paradigmatic tale of mother/daughter/lesbic lover. The Althusserian Imaginary, on the other hand, sets in motion syntagmatic conjunctions of experience, language, folklore, history, Jungian psychoanthropology, and political economy. Some of these are authorized by "academic" type footnotes, that go so far as to appeal to the reader for the authorizing sources that will "legitimate" the statement. Some of these conjunctions in effect link together multiple ideologies of racist misogyny as it pertains to indian/mestizas. Simultaneously the Shadow Beast is metonymically articulated with Snake Woman, Coatlicue, Guadalupe, La Chingada et al., and concatenated into a symbolic metaphor through which more figures are generated to produce the axial paradigm -the totalizing repression of the lesboerotic in the fabulation of the nation-state. The chronicle effect, however, is primarily produced through the syntagmatic movement of a collective text one may call "panmexican", yet relocated to the borderlands, thus making the whole of it a Chicano narrative. The indigenous terms and figurations have filtered through the Spanish-language cultural text, the code switching reveals the fissures and hybridity of the various incomplete imperialist/neocolonial projects. The terms and figurations preserved through the oral traditions and/or folktalk/streettalk coexist uneasily with "straight/talk", i. e. Standard Spanish and Standard English, all of which coexists uneasily with scholarly citations. The very "Symbolic Order" that "unifies" in Anzaldúa's text, the production, organization and inscription of mestiza consciousness is granted the task of deconstruction.

In short, then, Coatlicue (or almost any of her metonymically related sisters) represents the non(pre)-oedipal (in this case non(pre)-colombian) mother, who displaces and/or coexists in perennial interrogation of the "Phallic Mother", the one complicitous in the Freudian "family romance". Coatlicue is released as non(pre)-oedipal and non-Phallic Mother:

And someone in me takes matters into our own hands, and eventually, takes dominion over serpents —over my own body, my sexual activity, my soul, my mind, my weaknesses and strength. Mine. Ours. Not the heterosexual white man's or the colored man's or the state's or the culture's or the religion's or the parents' - just ours, mine. [...] 
And suddenly I feel everything rushing to a center, a nucleus. All the lost pieces of myself coming flying from the deserts and the mountains and the valleys, magnetized toward that center. Completa. ${ }^{28}$

Anzaldua resituates Coatlicue through the process of the dreamwork, conjures her from non-conscious memory, through the serpentine folklore of her youth. The desire to center, to originate, to fuse with the feminine/ maternal/lover in the safety of an Imaginary "third country", the borderlands disidentified from the actual site where the nation-state draws the juridical line, where formations of violence play themselves throughout miles on either side of the line: "she leaves the familiar and safe homeground to venture into the unknown and possibly dangerous terrain. This is her home/this thin edge of/ barbwire". ${ }^{29}$ The sojourner is as un-documented as some maquila workers in southern California. In this fashion the syntagmatic narratives, as an effect in profound structural complicity with ideologies of the nonrational "Shadow Beast", contribute to the discursive structuration of the speaking subject who links them to figures (like Coatlicue) of paradigmatic symbolicity recodified for ethical and political intent in our time, engaged in the search, in Anzaldúa's vocabulary, for the "third space". Anzaldúa destabilizes our reading practices as autobiographical anecdotes, anthropology, ideology, legend, history and "Freud" are woven together and fused for the recuperation which will not go unrecognized this time around.

When Gloria says she knows "things older than Freud", notwithstanding the whispering effect of such a brief phrase, she is, I think, announcing her plan to re(dis)cover what his system, and in Lacanian terms the patronymic legal system, displaces. This is so especially with reference to the oedipal/family-romance drama. The Freudian/Lacanian systems are contiguous to rationality, the "Man of Reason", the subjectconscious-of-itself-as-subject, insofar as such a subject is its point their departure. ${ }^{30}$ Thus the system that displaces the Maternal Law, substitutes it with the concept of the "unconscious" where the so-called "primal repression" is stored so that consciousness and rationally may be privileged specially as the constituted point of departure for the discovery of the "unconscious", further it constitutes itself as the science-making project displacing what thereafter be known as mythological systems,

\footnotetext{
28 Ibid., p. 51.

${ }^{29}$ Ibid., p. 13.

${ }^{30} \mathrm{~J}$. LACAN, op. cit.
} 
that is the "unconscious-as-the-discourse-of-the-Other"'s multiple systems of signification, to which the maternal/feminine is also imperfectly vanished. In a sense Anzaldúa's eccentricity-effected through non-Western folk/myth tropes and practices as recent as yesterday in historical terms, through the testimonies textually conserved after the conquest, and more recently excavated in 1968 by workmen repairing the Mexico city's metro-constructs a tale which is feminist in intent. It is feminist insofar as through the tropic displacement of another system she re(dis)covers the mother and gives birth to herself as inscriber/ speaker of/for mestiza consciousness. In Julia Kristeva's words, "Such an excursion to the limits of primal regression can be phantasmatically experienced as a "woman-mother". However, it is not as a "womanmother" that Anzaldúa's narrator actualizes the lesboerotic "visitation" of Coatlicue but as daughter and "queer". While Kristeva gives us a sanitized "homosexual facet of motherhood" as woman becomes a mother to recollect her own union with her mother. Though in her early work Kristeva posited the semiotic "as the disruptive power of the feminine that could not be known and thus fully captured by the masculine symbolic", she has "turned away from the attempt to write the repressed maternal or the maternal body as a counterforce to the Law of the Father". ${ }^{31}$ We are left instead with a theorization of the "maternal function" in the established hierarchy of the masculine symbolic. ${ }^{32}$ Gloria's narrator, however, represents the fusion without the mediation of the maternal facet itself. In Kristeva's text the "sanitization" takes place on the plane of preserving rather than disrupting the Freudian/ Lacanian oedipal/family-romance systems, not to mention the triadic Christian configuration. ${ }^{33}$

Anzaldu'a's rewriting of the feminine through the polyvalent Shadow Beast is an attempt to reinscribe what has been lost on the one hand through colonization - she says "Lets's root ourselves in the mythological soil and soul of this continent", ${ }^{34}$ and on the other, to reinscribe it as the contemporaneous codification of a "primary metaphorization" as Irigaray has posited - the repressed feminine in the Symbolic Order of the Name of the Father as expressed in the Lacanian rearticulation of Freud and the

${ }^{31}$ Drucilla CORNELL, Beyond Accommodation: Ethical Feminism, Deconstruction and the Law, p. 7.

${ }^{32}$ Idem.

${ }^{33}$ J. KRISTEVA, Desire in Language: A Semiotic Approach to Literature and Art, p. 239.

34 Ibid., p. 68. 
Western metaphysic. ${ }^{35}$ According to Irigaray, the psychic organization for women under patriarchy is fragmented and scattered so that is also experienced as dismemberment of the body, that is "the nonsymbolization" of her desire for origin, of her relationship to her mother, and of her libido, acts as a constant to polymorphic regressions (due) to "too few figurations, images of representations by which to represent herself". ${ }^{36}$ I am not citing Irigaray so that her work can be used as a medium for diagnostic exercises of Anzaldúa's work as "polymorphic regressions". Anzaldúa's work is simultaneously a complicity with, a resistance to, and a disruption of Western psychoanalysis through systems of signification drastically different from those of Irigaray herself, for example. Yet the simultaneity of conjunctures is constitutive of Anzaldúa's text itself. Indeed what Irigaray schematizes as description is the multiple ways in which the "oedipal/family-romance", whatever language-form it takes, makes women sick even as it tries to inscribe her resitance as illness already. The struggle for representation is not an inversion per se, rather the struggle to heal through rewriting and textualization yields a borrowing of signifiers from diverse monological discourses as Anzaldúa does in an effort to push towards the production of another signifying system that not only heals through re-membering the paradigmatic narratives that recover memory and history, but also rewrites the heterogeneity of the present. The desire is not so much a counterdiscourse as that for a disidentificatory one that swerves away and begins the laborious construction of a new lexicon and grammars. Anzaldúa weaves self-inscriptions of mother/daughter/lover which if unsymbolized as "primary metaphorization" of desire will hinder "women from having an identity in the symbolic order that is distinct from the maternal function and thus prevents them [us] from constituting any real threat to the order of Western metaphysics", ${ }^{37}$ or if you will the national/ ethnonational "family romance". Anzaldua is engaged in the recuperation and rewriting of that feminine/ist "origin" not only in the interfacing sites of various symbolizations but the geopolitical border itself $-E l$ Valle. ${ }^{38}$

${ }^{35}$ Judith BUTLER, "Gender Trouble, Feminist Theory, and Psychoanalytic Discourse", in Nancy FraSER and Linda J. NiCHOLSON, eds., Feminism/Postmodernism.

${ }^{36}$ Luce IRIgARAY, Speculum of the Other Woman, p. 71.

${ }^{37}$ Ibid., p. 71.

38 Sonia Saldivar-Hull, "Feminism on the Border: From Gender Politics to Geopolitics", in Héctor CALDERón and José D. SALdIVAR, eds., Criticism in the Borderlands: Studies in Chicano Literature, Culture, and Ideology. 
Anzaldúa's "Shadow Beast" intratextually recodified as Snake Woman, La Llorona, and other figurations, sends her stand-in forth as an Outlaw, a Queer, a "mita y mita", a fluid sexuality, deployed through cultural space, the borderlands, which stand within sight of the patronymic LAW, and where except those who possess it are Outlaws, endlessly represented as alterities by D. C. and D. F. Borderlands/La Frontera is an "instinctive urge to communicate, to speak, to write about life on the borders, life in the shadows", the preoccupations with the inner life of the Self, and with the struggle of that Self amidst adversity and violation with the "unique positionings consciousness takes at these confluent streams" of inner/outer. An outer that is presented by the Texas-U. S., Southwest/ Mexican border "and the psychological borderlands, the sexual and spiritual borderlands". ${ }^{39} \mathrm{~A}$ self that becomes a crossroads, a collision course, a clearinghouse, an endless alterity who once she emerges into language and self-inscription, so belated, appears as a tireless peregrine collecting all the parts that will never make her whole. Such a hunger forces her to recollect in excess, to remember in excess, to labor to excess and produce a text layered with inversions and disproportions, which are functions of experienced dislocations, vis-a-vis the text of the Name of the Father and the Place of the Law.

The contemporaneous question then is how can this continue to be rewritten in multiple ways from a new ethical and political position and what might it imply for the feminine in our historical context, especially for women of Mexican descent and others for whom means migrations to the electronic, high-tech assembly work on both sides of the U. S.Mexican border.

\section{Works Cited}

Alarcón, Norma, "Chicana Feminisms: In the Tracks of the Native Woman", in Cultural Studies, 1990.

ALthusser, Louis, Lenin and Philosophy and Other Essays. Trans. Ben Brewster. New York, Monthly Review Press, 1971.

AnZaldúa, Gloria, Borderlands/La Frontera: The New Mestiza. San Francisco, Spinsters/Aunt Lute, 1987.

${ }^{39}$ G. ANZALDÚA, op. cit., pref. 
Butler, Judith, "Gender Trouble, Feminist Theory, and Psychoanalytic Discourse", in Nancy FraSER and Linda J. NICHOLSON, eds., Feminism/ Postmodernism. New York, Routledge, 1990, pp. 324-340.

Castoriadis, Cornelius, The Imaginary Institution of Society. Trans. Kathleen Blamey. Cambridge, The MIT Press, 1987.

CoRneld, Drucilla, Beyond Accommodation: Ethical Feminism, Deconstruction and the Law. New York, Routledge, 1991.

DERRIDA, Jacques, Margins of Philosophy. Trans. Alan Bass. Chicago, University of Chicago Press, 1982.

FraSER, Nancy and Linda J. NiCholson, "Social Criticism without Philosophy: An Encounter between Feminism and Postmodernism", in N. FRASER and L. J. NicholsON, eds., Feminism/Postmodernism. New York, Routledge, 1990, pp. 19-38.

Herrera-Sober, Maria, The Mexican Corrido: A Feminist Analysis. Bloomington, Indiana University Press, 1990.

IrIgaray, Luce, Speculum of the Other Woman. Trans. Gillian C. Gill. Ithaca, Cornell University Press, 1985.

Jameson, Fredric, Postmodernism, or The Cultural Logic of Late Capitalism. Durham, Duke University Press, 1991.

KRISTEVA, Julia, Desire in Language: A Semiotic Approach to Literature and Art. Ed. Leon S. Roudiez. Trans. Thomas Gora, Alice Jardine y Leon S. Roudiez. New York, Columbia University Press, 1980.

LaCan, Jacques, Ecrits. Trans. Alan Sheridan. New York, W. W. Norton, 1977.

Limón, José E., Mexican Ballads, Chicano Poems: History and Influence in Mexican-American Social Poetry. Berkeley, University of California Press, 1992.

Lyotard, Jean-François, The Differend: Phrases in Dispute. Minneapolis, University of Minnesota Press, 1988. 
MALRKI, Liisa, "National Geographic: The Rooting of People and the Territorialization of National Identity Among Scholars and Refugees", in Cultural Anthropology: Space, Identity, and the Politics of Difference. Eds. James Ferguson and Akhil Gupta, 7(1), 1992, pp. 24-44.

Montejano, David, Anglos and Mexican in the Making of Texas, 18361986. Austin, University of Texas Press, 1987.

Nathan, Debbie, Women and Other Aliens: Essays from the U. S.Mexican Border. El Paso, Cinco Puntos Press. 1991.

Paredes, Américo. With a Pistol in His Hand: A Border Ballad and Its Hero. Austin, University of Texas Press. 1971.

Saldivar-Hull, Sonia, "Feminism on the Border: From Gender Politics to Geopolitics", in Héctor CALDERón and José D. SALDfVAR, eds., Criticism in the Borderlands: Studies in Chicano Literature, Culture, and Ideology. Durham, Duke University Press, 1991, pp. 203-220.

SMITH, Valerie, "Black Feminist Theory and the Representation of the 'Other'", in Changing Our Own Words: Essays on Criticism, Theory, and Writing by Black Women. Ed. Cheryl A. Wall. New Brunswick, Rutgers University Press, 1989, pp. 38-57.

TrinH T., Minh-ha, "Not You/Like You: Post-Colonial Women and the Interlocking Questions of Identity and Difference", in Making Face, Making Soul/Haciendo Caras, Creative and Critical Perspectives by Women of Color. Ed. Gloria Anzaldúa. San Francisco, Aunt Lute Foundation, 1990, pp. 371-375. 